\title{
Mathematical stories: why do more boys than girls choose to study mathematics at AS-level in England?
}

\author{
Heather Mendick
}

In this paper I address the question: How is it that people come to choose mathematics and in what ways is this process gendered? I draw on the findings of a qualitative research study involving interviews with 43 young people all studying mathematics in post-compulsory education in England. Working within a post-structuralist framework, I argue that gender is a project and one that is achieved in interaction with others. Through a detailed reading of Toni and Claudia's stories I explore the tensions for young women who are engaging in mathematics, something that is discursively inscribed as masculine, while (understandably) being invested in producing themselves as female. I conclude by arguing that seeing 'doing mathematics' as 'doing masculinity' is a productive way of understanding why mathematics is so male dominated and by looking at the implications of this understanding for gender and mathematics reform work.

\section{Introduction}

In England, the evolving gendered patterns of attainment in mathematics need to be juxtaposed with the unchanging gendered patterns of participation in the subject. There are few remaining differences between the attainment of males and females in either GCSE-level, AS-level, or A-level mathematics (taken at ages 16+, 17+ and 18+, respectively) (Gorard et al., 2001; The Guardian, 2002a, 2002b, 2003a, 2003b). Although boys remain more likely to secure the top grades, the differences are small and getting smaller. In contrast to these shifting patterns of attainment, the decision to continue with advanced mathematics remains highly gendered. This polarisation persists despite decades of feminist intervention; as Shaw (1995, p. 107) says, 'the most striking feature of subject choice is that the freer it is, the more gendered it is'. In fact, as Figure 1 shows, from 1994 to 2003 the proportion of the total number of 17 and 18 year olds entered for A-level mathematics in England who are male changed little, dropping only slightly from 65\% to 63\% (Government Statistical Service, 1995, 1996, 1997, 1998, 1999, 2000, 2001, 2002; The Guardian, 2002b, 2003b). This greater participation of males in mathematics courses becomes more pronounced as you progress through the levels - AS-level, A-level, undergraduate, and then postgraduate - and is reflected in the larger number of men than women working in mathematically oriented fields. There is a similar pattern of gendered participation in mathematical activities in other countries (Hanna, 1996; Boaler, 2000; Blattel-Mink, 2002).

Mathematics is a powerful subject, a signifier of intelligence that acts as a 'critical filter' (Sells, 1980) controlling entry to high-status areas of academia and employment. Thus, for those concerned with social justice, it is pertinent to ask: How is it that people come to choose mathematics and in what ways is this process gendered? This is the question that I address in this paper.

I do this by analysing two interviews drawn from a larger study that involves interviews and observations of 43 young Londoners who have chosen to continue studying mathematics beyond the end of compulsory education. In the interviews students were asked to describe a typical mathematics lesson, about what they had enjoyed most and least about mathematics, for their feelings on different teaching styles, to compare mathematics with other subjects, to explain their subject choices and their future plans, and for their feelings on gender. I analysed these interviews as narratives-of-self and then developed connections between them, dividing the participants into five groups by their main reason for choosing mathematics: 'for enjoyment', 'for chosen career and for enjoyment', 'for chosen career and NOT for enjoyment', 'to prove something to others' and 'to prove something to themselves'. In an earlier paper (Mendick, 2003) I told stories of three of the male participants who were using mathematics 'to prove something to others'. Simon chose mathematics, in spite of the way its curriculum violates his notions of 'commonsense', in order to 
prove his worth to potential employers; James also chose mathematics as a way of securing his future within the labour market; Michael chose mathematics in order to use its reputation as a hard subject to prove his intelligence to those around him. I argued, using work on school masculinities (for example, Connell, 1989; Mac an Ghaill, 1994), that, in choosing mathematics, these boys were doing masculinity.

Figure 1. Participation in A-level mathematics by gender

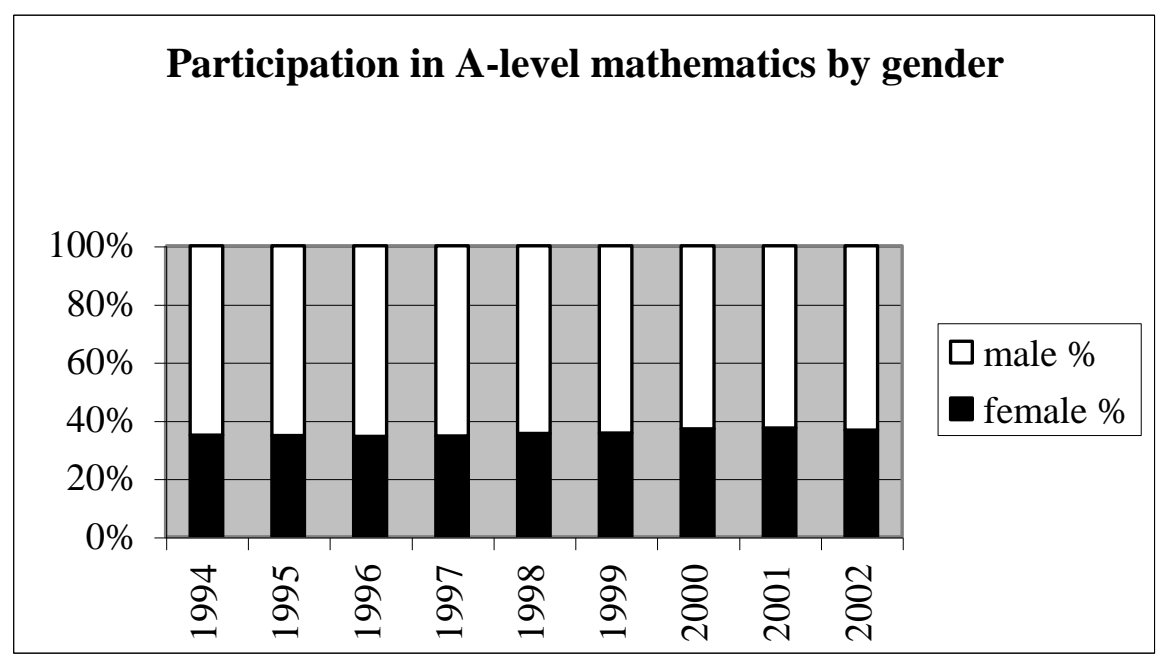

Note: in the published paper the graph goes to 2003 - there's little change

This paper is an exploration of the possibilities of applying this idea, that doing mathematics is doing masculinity, to the girls in my study. I develop my argument using detailed readings of the stories of two participants, Toni and Claudia. Toni is in the same group ('to prove something to others') as Simon, James and Michael, and the similarities and differences between her story and those others are central to my exploration of how performances of masculinity, such as doing mathematics, affect and are affected by one's daily existence as a woman. Claudia's group ('to prove something to themselves') is the smallest of the five with only three members, all of whom are female. As a member of the only all-female grouping, Claudia's story offers a good contrast with Toni's, which is drawn from the most male-dominated of the groups with only two girls among its eight members, and so gives a sense of the versatility and the possibilities of my approach.

In the mathematics education literature it is commonly argued that the masculinity of mathematics makes it more problematic for girls and women to choose and succeed at the subject than for boys and men. However, my aim here is to use this unusual theoretical approach, of seeing doing mathematics as doing masculinity, whether the doer is male or female, to imbue this idea with new meanings and understandings and to look at what these might have to say about changing gender and mathematics through education. Thus, before turning to Toni and Claudia's stories I explain the differences between my own approach to the question and others in the literature.

\section{Differing lenses on 'the problem of girls and mathematics'}

Explanations of the gender imbalance in participation in mathematics are usually split into two categories - biological and sociological — with these being seen as directly opposed (Dunne \& Johnston, 1994). In contrast, I argue here that they share some key assumptions about gender and, in particular, the ways in which the relationships between the terms in the following interlinked oppositions are imagined:

- Biological/social.

- Individual/social.

- Gender/sex.

- Masculine/feminine. 
Alongside this, I develop my alternative post-structuralist approach showing how differently it imagines these relationships. Biological explanations are generally based on average gender differences in measures of 'spatial and mathematical abilities' or in measures of self-esteem, confidence and anxiety. These data are then theorised using arguments from evolutionary psychology. The problems with biological explanations are well rehearsed. I mention just two points that are central to my argument. First, within such arguments biology exists as a category that can be separated from social processes. However, biology always functions in a social context and is unthinkable outside it (Fausto- Sterling, 1985; Connell, 1987; Caplan et al., 1997; Boler, 1999). Second, within such arguments individuals are also viewed as separable from sociocultural practices. This had particularly damaging consequences when applied to explanations based in female lack of self-esteem, confidence, and so on, where the psychological approach meant that researchers "had "no idea" how this might arise-these characteristics were, it seems, a corollary to being born female' (Willis, 1995, p. 189). Thus, these arguments construct 'the problem of girls and mathematics' as residing within the girls (for critiques see Kenway \& Willis, 1990; Chetcuti \& Griffiths, 2002). It is in an attempt to avoid this that I, like many others, have turned to sociological explanations.

Feminist researchers have generated a large number of sociological explanations for the male dominance of education generally, and of mathematics in particular. The main ones are lack of female role-models, widespread gender stereotyping, boys' dominance of educational spaces, sexual harassment in educational institutions, the gendered nature of knowledge, and gendered preferences for different teaching, learning and assessment styles. Theoretically these are based in the idea that boys and girls have different experiences and so develop different 'abilities' and interests via a process of sex-role socialisation. In this way, it is argued, sex, the biological difference between men and women, is detached from gender, the sociological difference, so making change possible.

The sex/gender distinction works with an idea of the interaction of the biological and the social in the construction of individuals. This raises many questions, such as: What is it that is supposed to be interacting? (Birke, 1999) And, where are these interactions taking place? (Blackman, 2001) The problem is that the 'model of interaction (however complex an interaction is asserted) leaves the idea of an unmediated biology unchallenged' (Henriques et al., 1984, p. 21) and so results in basically the same construction of the biological/social dualism as operates in biological explanations. This forecloses possibilities of building new understandings of the role of biology in making us who we are.

However, I do not want to replace the model of the interaction of the biological and the social with a social constructionist position that dismisses biology altogether, engaging with it only to critique its reductionism. With Blackman (2001, p. 211), I am concerned that 'what is often overlooked is that "biology" as an object, shifts and changes in meaning and cannot pass as a stable, constant category, which we can simply reject', and so the biological/social dualism remains intact and we delegate to biology all discussions of what goes on beyond the surface of the body except for that small portion claimed by psychoanalysis (Birke, 1999). Instead I view biological and psychological processes 'as generative potentialities, which can be transformed through the strategies and practices we develop to identify and act upon these processes' (Blackman, 2001, p. 226).

This is a post-structuralist approach to the body. Regarding post-structuralist approaches to the relationship between the individual and the social, it is useful to compare these with sex-role socialisation, the process by which sexed individuals are thought to take on social gender.

Within the sex-role socialisation model of the world the child is taught her or his sex-role by, usually, one central adult, but is also 'pressed' into maintenance of that role by a multitude of others (peers, media etc.). There is no room in this model for the child as active agent, the child as theorist, recognising for him or herself the way the social world is organised. Nor is there acknowledgement of the child as implicated in the construction and maintenance of the social world through the very act of recognising it and through learning its discursive practices. (Davies, 1989, p. 5) 
The child is positioned as passive, as acted on, within the story of their socialisation. Moreover there is a simple model of cause and effect operating in which certain aspects of the social world are seen to be directly causing gendered behaviours in children (Henriques et al., 1984; Connell, 1987; Walkerdine, 1998). Again the individual is imagined as essentially distinct from the social.

Post-structuralism makes no such distinctions, instead referring to the process by which the child actively takes up their place within socio-cultural discourses as subjectification rather than socialisation (Davies, 1993). It was because I wanted to examine the ways in which people write themselves/are written in and through socio-cultural discourses that I used a narrative approach to analysing my data. Discourses are "practices that systematically form the objects of which they speak' (Foucault, 1972, p. 49). These knowledges about objects are powerful because they determine what can be said, as well as who can say it, and even what can be thought or imagined. Thus, these discourses are seen as operating within regimes of truth, not because of their power to describe reality, but because of their power to produce it. Central to post-structuralist conceptions of the self is the process of subjectification through which people take up positions in discourses. Discursive practices are imagined as negative and positive, oppressive and productive, simultaneously and always.

If power were never anything but repressive, if it never did anything but to say no, do you really think one would be brought to obey it? What makes power hold good, what makes it accepted, is simply the fact that it doesn't only weigh on us as a force that says no, but traverses and produces things, it induces pleasure, forms knowledge, produces discourse. It needs to be considered as a productive network which runs through the whole social body, much more than as a negative instance whose function is repression. (Foucault, 1980, p. 119)

Thus power is exercised locally and wherever there is power there is also resistance. This idea captures the double-edgedness of power and is the basis of a conceptualisation of agency (see Butler, 1993). The notion that 'oppressive' discursive positionings carry immense pleasure and power for the individuals occupying them is central to my readings of Toni and Claudia's investments in femininity, mathematics, and other discursive practices. Summarising, it is within a range of discourses on mathematics, masculinity, femininity, education and much more that an individual's educational choices and experiences come into being. So instead of asking 'Why do girls/boys engage in specific practices?', the question is reversed to ask 'How do specific practices do girls/boys?' (Flax, 2002). Masculinity and femininity are viewed as fluid properties of practices not people. 'Gender is always a doing, though not a doing by a subject who might be said to preexist the deed' for 'there is no gender identity behind the expressions of gender; that identity is performatively constituted by the very "expressions" that are said to be its results' (Butler, 1999, p. 33). Female-ness and male-ness are produced through reiterative performances, in such a way that they appear to precede these performances, and so are experienced as authentic/natural by the performer/ possessor. Importantly, if sex and gender are seen as independent, then, even if a binary form of sex is assumed, there is no necessary reason why there should be only two genders nor why male bodies should become gendered as masculine and female bodies as feminine (Butler, 1999). These ideas amount to a radical transformation of the relations between the biological, the social and the individual in making-up gendered people. To demonstrate their value I use them to understand Toni and Claudia's mathematical choices and experiences.

\section{Toni's story}

Toni was 'born here [England]. But then I moved to America when I was like five. So I came back in June and my mum is from Africa, in Gambia. My dad is half Jamaican ... my mum is half Nigerian and half Gambian'. Her father died nine years ago and her mother is a flight attendant. Toni is studying biology, chemistry, and mathematics. She chose these because of her desire to be a doctor.

I just like curing people [and] prescribing things, you know. Telling them: 'take this and you'll feel better!' ... Basically I just wanna be the person that knows everything. Like when you're sick yeah, I wanna be the one to tell you that 'OK take this thing yeah and when you take it you'll feel better and 
stuff.' I just like, just helping people I guess ... And I like working with kids also.

Toni mentions several reasons for wanting to be a doctor in this passage but her desire to control others comes first, is stated with greater force and enthusiasm, and seems to be her central reason; the traditional feminine roles of helping others and caring for children appear to be added as afterthoughts. She wants the status, respect and influence that come with medical qualifications. Similar motivations are present in her relationship with mathematics. Toni has little to say about a typical mathematics lesson, she mentions only the length of the lesson and her grades: 'It was great. Besides the timing was really short. I mean it was really quick. You know that was the only thing. But it was all right. I mean I had good grades anyway so, I was OK'. One way that Toni uses mathematics to position herself as powerful is through obtaining good grades. Within the interview she displays a strong orientation around getting the qualifications necessary for her future plans. This is the reason that she gives for studying in England rather than America: 'When you have like your ... certificate that you get for taking your AS, it's really good when you go back to America because you can easily get a university ... That's why I'm here'.

However, it is not just the good grades Toni gets that enable her to use mathematics to feel powerful. That she is using the status of mathematics as a signifier of intelligence is evident in the discussion of what other people, not doing mathematics, think of the subject: 'they think maths is so hard. And whoever's doing maths is so brainy. That's what everybody thinks'. We then go on to talk about subject stereotypes more generally and I ask from where she thinks they come:

OK someone like me I'll go and I'll be, 'I want to be so smart' or 'I want them to think that I'm so smart' and I'll go 'Oh my god, maths was so hard! You should see, look at this $x, x, x$.' Just to make them think that I'm so smart you know. And then they'll be like 'oh my god she's smart' you know, something like that.

Toni's recognition of the power of mathematics is coupled with scepticism about the subject's utility. In the interview she asks 'What's the use of maths?', explaining:

when you graduate or when you get a job, nobody's gonna come into your office and tell you: 'can [you] solve $x$ square minus you know?' ... It really doesn't make sense to me. I mean it's good we're doing it. It helps you to like crack your brain, think more and you know, and all those things. But like, nobody comes [to] see you and say 'can [you] solve this?'

So Toni's attachment to mathematics is related to her desires to have power over others, to be thought intelligent by them and to build her future relationship with the labour market. In other words, very similar to those of the boys in her group-Simon, James and Michael. In their cases I have no problems reading such a pattern of identifications as part of their masculine identity projects, but I have more difficulties and discomforts in Toni's case because she 'is' female. In order to make sense of how masculine performances are affected by living on the female side of the gender binary, I borrow the term 'gender category maintenance work' from Davies (1989, p. 29). Davies devises this concept to make sense of children's actions, including 'what adults often see as incomprehensible nastiness on the part of small children', to maintain the categories of male and female against deviancy and to confirm the social competence of those doing it. She explains their thought processes running:

I may feel sorry for you, I may even have a fascination with the way you are doing your masculinity [or femininity], but my aggression is essential in defining what you do as a transgression and clarifying for myself that I have got it right. One might say that the 'deviants' are necessary for making stronger boundaries. Thus deviation does not change the category, but is used as an opportunity to shore the category up. (Davies, 1989, p. 29)

My use here is a little different from (but in the spirit of) Davies' in that I apply the term to adults' (as well as to children's) behaviours and think of it as applying to the policing of one's own actions as well as to those of others. For example, there is evidence that people who make non-gender traditional subject choices, in general, have more conservative views on other aspects of gender roles (Thomas, 1990; Whitehead, 1996), as if their gender category maintenance work demands 
such conformity to compensate for their 'transgressions' in other areas. In the rest of Toni's story, I want to consider how she compensates for the gender transgression of doing mathematics and so to explore the tensions between doing masculinity and 'being' female. I do this by looking at her contradictory experiences of femininity.

Toni tells me:

Sometimes I wish that I was a boy ... Coz you know why? Boys are really easy going ... Basically I say that because like, girls are really, they take too much time first off, like making their nails doing their hair ... If I was going to a party tonight, I would've been planning it since last week or even last month talking about 'oh what dress shall I buy, you know that silver one,' or talking about 'oh my nails, my hair.' You know, boys just cut their hair, take some trousers, any kind of trousers, some nice shirt, it don't even have to be nice, some full shoes, and they are gone. Nothing else. Nothing else. But us it's just too much work.

Toni describes the huge amount of time she devotes daily to getting ready for college. She finds this draining and in the next passage she questions its necessity, although she also feels obliged to continue.

If you think about it, there's no point to it, because like, OK you just want to feel good, you know. But it's not like you coming to school to attract anybody. So somehow it doesn't make any sense, you taking your time dressing, but you know, trying to look good. But in some other way, you're trying to just feel good about yourself. So it's really different. It's two different things. People dress for boys, some girls, and some girls just dress because they feel like dressing that way and some people just wanna look good. But some people say, 'oh she ain't got no money' or something like that 'she's poor' or something.

Toni's views are reminiscent of those of the white working-class female students in Skeggs' (1997) research, who found their physical presentation proscribed by the powerful notion of 'respectability'.

They operate with a dialogic form of recognition: they recognize the recognitions of others. Recognitions do not occur without value judgements of real and imaginary others. Recognition of how one is positioned is central to the processes of subjective construction. (Skeggs, 1997, p. 4; original emphasis)

Along with one of Skeggs' participants, Toni evokes 'a sense of being caught up in something which is beyond her control'; the risks of getting out are too great, hazarding 'cultural stigmatisations in her local situation; a challenge to all her friends who collude in femininity; a sign of difference' (Skeggs, 1997, p. 102). In this discussion I argue that, while being masculine carries an appeal for Toni, she is also (understandably) heavily invested in producing herself as female, both in her own eyes and in other people's. In order to do this she draws on the discursive practices that produce people as masculine or feminine. The tension in these passages between wanting to dress recklessly like a man and wanting to be recognised through her dress as a woman, suggest that we could understand there being similar tensions contained in her desire, discussed earlier, for masculine control and mathematical success within education and employment, and her desire to be recognised through her actions in these fields as a woman. Thus, while Toni's desire for and envy of masculinity are tangible, there are conflicts with the demands placed on her to maintain her position within the category 'woman'. Among other things these tensions and conflicts make it more difficult for her to consistently and comfortably inhabit a position as mathematically successful. I continue my exploration of the tensions that are experienced by young women studying mathematics in Claudia's story.

\section{Claudia's story}

Claudia, an ambitious young woman, is interested in becoming a barrister. Her family moved from Algeria to Scotland when she was four years old, and then later to London. In her interview she distances herself from her childhood; for example, through her absence from the phrases 'my mum and dad are from Algeria' and 'they lived there till I was four and a half'. She is studying five subjects, instead of the usual four, but 'if you could do six, I'd be doing six' because 'I don't feel 
alright, if I'm not doing, if I know I'm not doing the hardest thing possible, I'm not really exerting myself, I don't like it'. Her subject choices - chemistry, English literature, French, history and mathematics - cut across the academic curriculum. They represent Claudia's desire for challenge as well as her self-presentation as sophisticated (she prefers to sit at the back of the class and is disdainful of those eager to answer questions), 'defiant' ('I don't [take] things as they're told to me') and determined. She also jokingly describes her programme of study as 'self-torture', suggesting that it is associated with pain, as it is for the middle-class women in Walkerdine et al. (2001, p. 179) whose 'educational lives had been rigidly circumscribed by the expectations of academic success, often to such an extent that quite outstanding performances were only ever viewed as average and ordinary'. This ambiguity can be read in Claudia's subject choices. With French she clearly wanted a challenge: 'I went to France last year, in the summer sorry, and I realised I wasn't quite as good at French as I always thought I was, so I thought I should take it up'. She is trying to prove that she is as good at French as she thought she was and clearly thinks she should be. However, because Claudia keeps raising her academic targets, I doubt she will ever be able to do enough to prove herself to herself. Thus, this continual challenge seeking may be both destructive and productive. This double edged-ness is clearer in her talk about mathematics.

Claudia employs a militarist metaphor to explain her choice of mathematics: 'I like the fact that I've got to conquer these numbers'. However, as well as her evident pleasure in the power she gets from such conquests, she explains:

sometimes I dread going into [maths], 'oh now I've got maths' but I think that's just because of the ... stigma attached to maths. It's like, 'oh, maths, numbers, er'. I don't dislike it. It's not my favourite subject. I'm doing it, I'm doing maths sort of because I know it will be a challenge to me and it's useful and it's good, I think it's good for your brain to do maths.

These painful aspects of Claudia's mathematical identifications are also manifest in the way she froze in her GCSE examination: 'I was so scared of not having done enough maths revision', so when 'I went into the exam for the first few minutes I was just really scared stiff, I couldn't do anything. I just kept staring at the first page and just reading it and not taking it in at all'.

In explaining Claudia's 'dread', her account of being sent, aged 12, to special mathematics classes is important.

I was like always top in the class, top in the year, and ... myself and a couple of other students were selected from the year to go to these advanced maths classes ... And they were really, really hard. [The classes covered] really super, super maths for really clever people ... and so me and my friend would just sit there and sort of draw, doodling and so, I think, there's often been times when I've like been inclined to be scared of maths coz of not understanding it.

Claudia's fear relates both to the gendered myth of mathematical genius (Mendick, 2005) and to the constant threat of just 'not understanding it', and so of being judged inadequate/wrong (Buxton, 1981).

Her experience of mathematics can be read as gendered in two further ways. First, she tells me that, while she has always been 'good at mental arithmetic' and 'just thinking in numbers comes quite naturally to me', she has problems with 'harder maths'. This distinction draws on the gendered discursive oppositions reason/calculation and hard/easy (Walkerdine, 1988, 1997). Second, despite negative feelings, she chose mathematics. The high-status intellectual challenge that mathematics represents is central to this, but so are her teachers. Claudia's version of mathematics is relational: '[Mathematics] really depends on the person you have teaching you'. She tells me that, in GCSE, 'the first teacher I had I didn't really gel with him so ... I didn't feel I really achieved anything' but the following year a 'really good' teacher took over. When I ask why this teacher was so good, Claudia hesitates then observes:

[an] odd coincidence was that the teacher who I had for [ages 11-14] was a lady, and the teacher who I found to be good was also a lady ... I think it was ... the way she treated us, the way she spoke to us, especially like my little group ... it was more personal. 
However, despite this, Claudia is reluctant to read the influence of gender into her educational choices. After she has talked briefly about possible physiological and sociological reasons for the gendering of subject choice, I ask about the general impact of gender on her life. In contrast to Toni, Claudia says nothing about how she inhabits her femininity. Instead she explains:

I read something about if you're a barrister, female barrister, you have to accept that men will go further than you, which I think is a bit 'er, no they won't!' I want to be the best'. [We laugh.] Obviously men still get better pay, don't they? Erm, I don't know, I'm not really a feminist. I don't think that, I don't know all about that equality thingy and stuff ... I think if you're male then you have more of a chance of being more career orientated and even if you're not career orientated, coz well women produce children, funnily enough, um it's sort of split between the two. So men are more likely to become leaders and more important people, have more jobs, and so it becomes a man's world really. And women are still um second-class. I mean I've heard that said a lot but I don't know how true it is ... It's becoming less and less true, but I think it is, it is true in sort of, in terms of the hard facts it is. Like figures and stuff. Who has what jobs, who earns what, who owns what, who has power, stuff.

Claudia's account of choices free from constraints can be disrupted by reading it in the context of Rose's (1999, p. ix) discussion of neo-liberalism's insistence that 'each individual must render his or her life meaningful as if it were the outcome of individual choices made in furtherance of a biographical project of self-realization'. These new forms of regulation can neither be understood as freedom, since 'the self is not merely enabled to choose, but obliged to construe a life in terms of its choices' (Rose, 1999, p. 231), nor as repression since they 'do not crush subjectivity. They actually fabricate subjects-human men, women and children-capable of bearing the burdens of liberty' ( $p$. vii). Claudia is reading herself through this fiction of the autonomous self (Walkerdine et al., 2001) that compels her resistance to connecting being female to lacking power and to disadvantage within her own life. Instead she attaches these to generalised others and to the impersonal realm of reports, statistics and theories. Although it is through this fiction that Claudia's desire to succeed at mathematics and as a barrister is constituted, it is one that carries more tensions for girls than for boys:

Now that girls can, in principle, take the place previously accorded to their brothers, their production as the bourgeois subject is a huge struggle and is never simply or entirely achieved, and certainly not without terrible penalties for body and mind. This view of what happens to the girls is in complete opposition to a simplistic notion of a genderquake as a freeing feminist triumph! (Walkerdine et al., 2001, p. 175)

I would argue that these tensions are particularly pronounced in the case of mathematics because of its key role in producing rational subjects and the gendered ways that it is constructed as absolute and abstract, and so as dis-embodied and disconnected. Before looking at possible interventions into these constructions, I draw together my analyses of Toni and Claudia.

\section{Endings 1: connecting Toni and Claudia}

Toni and Claudia show us how they use/are used by their educational choices to do their identity work. Mathematics is a powerful choice because its discursive construction allows it to function in their identity projects as a way of proving their 'abilities' to a range of imagined others, and to themselves. Taking a post-structuralist approach, the power of mathematics and hence its authority in saying something about oneself, is not something fixed and natural, but is a contingent product of the discourses through which it is constituted. Within the discourses that are central to the way that Toni, Claudia and my other participants negotiate a relationship with the subject, mathematics is different from other subjects; it is certain, challenging, hard, and unrelated to everyday life. Mathematicians are different from other people; they combine the flattering character of geniuses and heroes with the unflattering character of 'nerds' (Mendick, 2005). These discourses are oppositional and gendered; they inscribe mathematics as masculine, as do the discourses that relate mathematics to wage earning potential (McGavin, 1999) along with the continued gendering of participation in paid labour (Witz, 1997). Thus we can understand those engaged in the practices of mathematics as doing masculinities and so it is more difficult for girls and women to feel 
comfortable with mathematics, and so to succeed at and choose it.

Thus, I have argued through Toni and Claudia's stories that doing mathematics creates tensions for them because, while mathematics is discursively inscribed as masculine, their bodies are discursively inscribed as feminine, and it is this latter label that they are invested in producing as 'natural'. In the stories, the reasons that I offer for the gendering of the need to prove to yourself and others that you are good enough to do mathematics are based on a range of experiences - for example, of teachers, of friends and of bodies - that, in general, differ for girls and boys. I relate these to the way that, while both girls and boys are required to produce themselves as autonomous subjects, this is a process that is more problematic for girls than for boys.

This argument avoids essentialist thinking on gender difference by seeing gender as a social practice rather than an individual trait, deconstructing the oppositions:

- Biological/social.

- Individual/social.

- Gender/sex.

These students' behaviours are gendered because different social contexts elicit different behaviours and men and women have differential exposure to these contexts, and so the system becomes selfperpetuating (Bohan, 1997). In other words, both boys' and girls' subject choices represent attempts by young people to occupy powerful subject positions but their gender/identity projects make available different ways of being powerful.

This argument also avoids oppositional thinking on gender difference queering the binary:

\section{- Masculine/feminine.}

I have broken with the dominant pattern of research in gender and mathematics education, and in the sociology of gender more generally, that maps masculinities onto men and boys and femininities onto women and girls (Halberstam, 1998) and so tacitly reinforces oppositional conceptions of gender.

That people whose bodies are socially marked as feminine do things that are socially marked as masculine and vice versa is not surprising. However, that the marking of the body as male or female impacts on one's possibilities for acting is apparent in both Toni and Claudia's stories; not all positions are equally available to all people. Access to the available gendered subject positions is also cross-cut by differences of class, race/ethnicity, dis/ability and hetero/sexuality. Given the generally greater social valuation of facets of masculinity, it is not surprising that these hold out greater appeal for boys and girls than do facets of femininity. This has social justice implications. The analyses in this paper suggest that it is important to make a wider range of discursive positionings/stories available to a wider range of individuals. As Plummer (1995, p. 166) argued (in the rather different context of sexualities): 'It is not an easy option to keep the pluralistic, polyvocal potential of proliferating stories open; but it is probably a very necessary one'. I end with a brief look at the implications of this for gender and for mathematics reform work.

\section{Endings 2: changing gender and mathematics}

In a rare study of female masculinity, Halberstam (1998) points out that, while it may be easier to be a tomboy than a sissy, this does not carry through into adulthood. She argues that, while 'excessive conventional femininity often associated with female heterosexuality can be bad for your health' and 'tends to be associated with passivity and inactivity, [and] with various forms of unhealthy body manipulations from anorexia to high-heeled shoes' (Halberstam, 1998, p. 268), it is masculinity that is commonly viewed as dangerous for women and girls. There is a need 'to make masculinity safe' for us:

Although it seems counter-intuitive to suggest that such a project should be necessary in the 1990 s, it has been my contention that despite at least two decades of sustained feminist and queer attacks on the notion of natural gender, we still believe that masculinity in girls and women is abhorrent and pathological. (Halberstam, 1998, p. 268) 
However, femininity and masculinity are not two symmetric sets of practices from which people should be enabled to select at will. Current gender regimes are profoundly unequal and men still secure their 'patriarchal dividend' (Connell, 1995). I see the project of making masculinity safe for women (and femininity safe for men) as a way of transforming the practices and ways of being that currently support the oppression of women. After all, it is the exclusion of women (and men) from certain practices that allows them to function as part of a system of domination. So, the question is: how can mathematics teachers engage in this project of making masculinity safe for women and girls? One way is to acknowledge the problem and create spaces in which to talk about it. Damarin (2000) follows this route when she suggests setting up support groups similar to Alcoholics Anonymous for budding female mathematicians.

However, this option leaves mathematics itself unchanged. This is unacceptable since, if doing mathematics is doing masculinity, mathematical practices are implicated in preserving male domination. So mathematics must change and the starting point must be the myth of the certainty of mathematical knowledge, its epistemological status as absolute and untainted by the corruption and messiness of daily life. This gives mathematics its power and maintains it in its position as the ultimate intelligence test. However, it is an entrenched myth and one that makes it difficult to put alternative epistemologies into practice in the classroom. In order to point ways forward I use the two metaphors: voice and narrative. By basing my analysis around students' voices and stories, the 'objective' voice of mathematics has been put in its place allowing other voices to be heard. It is important to avoid essentialism here; there are no true voices. However, the idea of 'voice' is still useful. It enables me to acknowledge that we feel able to express some things in some places but not in others and that some of these processes feel authentic while some feel like silencing, and that these processes impact on what we can do in different spaces. I would suggest that allowing more voices into classrooms would mean teachers and students engaging with mathematics that is about more than right (and wrong) answers. It would mean adopting pedagogical practices that value the process of doing mathematics over the results obtained; ones in which students talk about different approaches to the same problem, debate the merits of different 'solutions' to the same problem, and see teachers and each other making mistakes and so learn to view these as part of mathematics rather than shameful things to be concealed (Hall, 2004).

However, hearing voices is not a neutral process. As the analytic work here illustrates, it is not enough to change practices so as to introduce more voices, it matters into which stories we insert the words we hear. Bibby (2001, p. 27) argues that 'school mathematics still lacks stories' and asks 'Is this one reason why some of us have such trouble understanding and relating to it?' I both disagree and agree with this. I disagree because, as this paper illustrates, there are stories about mathematics; to make meaning in any field, including mathematics, is to tell stories. I agree in the sense that these stories, for example, of mathematics as absolute and of mathematical 'ability' as natural, are of a very particular kind and are ones that create limited spaces for learners (and teachers).

Mathematical pedagogies, as my research has done, should actively work to embrace a wider range of stories through which to make sense of the cacophony of student voices. This means teachers engaging in the interlocking projects of changing their practices and their ideas about what mathematics is and how it can best be learnt. (Although this is something that is far from easy in the current examination and targetdriven educational system.) Many others have called for similar changes to mathematics (Skovsmose, 1994; Burton, 1996; Cotton, 2001; Boaler, 2002). My work supports their arguments that this would be a more inclusive and socially just curriculum than the current one. One in which more students than at present could come to think of themselves as what Povey calls author/ities in relation to mathematics:

An author is one who brings things into being. Who is the originator of any action or state of things. Authority is concerned with power and the validity of knowledge. Linked together they lead us to the construction of an epistemology which recognises each of us as the originator of knowledge. (1997, p. 332) 


\section{Acknowledgement}

This research was carried out at the Educational Studies Department, Goldsmiths College, New Cross, London SE14 6NW, UK. Thanks to Debbie Epstein, Dennis Atkinson, Leone Burton and Jo Warin for their help with this article and to the ESRC for their funding. 


\section{References}

Bibby, T. (2001) Primary school teachers' personal and professional relationships with mathematics . Unpublished Ph.D. thesis, King's College, University of London.

Birke, L. (1999) Feminism and the biological body (Edinburgh, Edinburgh University Press). Blackman, L. (2001) Hearing voices: embodiment and experience (London, Free Association Books).

Blattel-Mink, B. (2002) Gender specificity in subject perception and decision with main emphasis on science and technology, Equal Opportunities International, 21, 43-64.

Boaler, J. (2000) So girls don't really understand mathematics? Dangerous dichotomies in gender research, paper presented at the ICME9 Conference, Tokyo, Japan, 31 July - 6 August, London, IOWME. 29-44.

Boaler, J. (2002) Learning from teaching: exploring the relationship between reform curriculum and equity, Journal for Research in Mathematics Education, 33, 239-258.

Bohan, J. S. (1997) Regarding gender: essentialism, constructionism, and feminist psychology, in: M. M. Gergen \& S. N. Davis (Eds) Toward a new psychology of gender (London, Routledge).

Boler, M. (1999) Feeling power: emotions and education (London, Routledge).

Burton, L. (1996) Mathematics and its learning as narrative - a literacy for the twenty-first century, in: D. Baker, J. Clay \& C. Fox (Eds) Challenging ways of knowing: in English, maths and science (London, Falmer).

Butler, J. (1993) Bodies that matter: on the discursive limits of 'sex'(London, Routledge).

Butler, J. (1999) Gender trouble: feminism and the subversion of identity (London, Routledge).

Buxton, L. (1981) Do you panic about maths? Coping with maths anxiety (London, Heinemann).

Caplan, P. J., Crawford, M., Hyde, J. S. \& Richardson, J. T. (Eds) (1997) Gender differences in human cognition (Oxford, Oxford University Press).

Chetcuti, D. \& Griffiths, M. (2002) The implications for student self-esteem of ordinary differences in schools: the cases of Malta and England, British Educational Research Journal, 28, 528-549.

Connell, R. W. (1987) Gender and power (Cambridge, Polity Press).

Connell, R. W. (1989) Cool guys, swots and wimps: the inter-play of masculinity and education, Oxford Review of Education, 15, 291-303.

Connell, R. W. (1995) Masculinities (Cambridge, Polity Press).

Cotton, T. (2001) Mathematics teaching in the real world, in: P. Gates (Ed.) Issues in mathematics teaching (London, RoutledgeFalmer).

Damarin, S. (2000) The mathematically able as a marked category, Gender and Education, 12, 6985 .

Davies, B. (1989) Frogs and snails and feminist tales: preschool children and gender (Sydney, Allen \& Unwin).

Davies, B. (1993) Shards of glass: children reading and writing beyond gendered identities

(Sydney,

Allen and Unwin).

Dunne, M. \& Johnston, J. (1994) Research in gender and mathematics education: the production of difference, in: P. Ernest (Ed.) Mathematics, education and philosophy: an international perspective (London, Falmer).

Fausto-Sterling, A. (1985) Myths of gender: biological theories about women and men (New York, Basic Books).

Flax, J. (2002) 'Concern for the self': rethinking subjectivity and ethics, paper presented at the Centre for Psychosocial Studies, Birkbeck College, London, UK, 3 July.

Foucault, M. (1972) The archaeology of knowledge (London, Routledge). 
Foucault, M. (1980), in: C. Gordon. (Ed.) Power/knowledge (Harlow, Prentice Hall).

Gorard, S., Rees, G. \& Salisbury, J. (2001) Investigating the patterns of differential attainment of boys and girls at school, British Educational Research Journal, 27, 125-139.

Government Statistical Service (1995) Statistics of education: public examinations GCSE and GCE in England 1994 (London, HMSO).

Government Statistical Service (1996) Statistics of education: public examinations GCSE and GCE in England 1995 (London, HMSO).

Government Statistical Service (1997) Statistics of education: public examinations GCSE and GCE in England 1996 (London, HMSO).

Government Statistical Service (1998) Statistics of education: public examinations GCSE/GNVQ and GCE in England 1997 (London, HMSO).

Government Statistical Service (1999) Statistics of education: public examinations GCSE/GNVQ and GCE in England 1998 (London, HMSO).

Government Statistical Service (2000) Statistics of education: public examinations GCSE/GNVQ and GCE in England 1999 (London, HMSO).

Government Statistical Service (2001) Statistics of education: public examinations GCSE/GNVQ and GCE in England 2000 (London, HMSO).

Government Statistical Service (2002) Statistics of education: public examinations GCSE/GNVQ and GCE in England 2001 (London, HMSO).

Halberstam, J. (1998) Female masculinity (Durham and London, Duke University Press).

Hall, P. (2004) The end of spoon fed mathematics? A report of a year's BPRS research, Proceedings of the British Society for Research into Learning Mathematics, 24, 25-30.

Hanna, G. (Ed.) (1996) Towards gender equity in mathematics education: an ICMI study (Dordrecht, Kluwer Academic Publishers).

Henriques, J., Hollway, W., Urwin, C., Venn, C. \& Walkerdine, V. (Eds) (1984) Changing the subject: psychology, social regulation and subjectivity (London, Methuen).

Kenway, J. \& Willis, S. (Eds) (1990) Hearts and minds: self-esteem and the schooling of girls (Lewes, Falmer Press).

Mac an Ghaill, M. (1994) The making of men: masculinities, sexualities and schooling (Buckingham, Open University Press).

McGavin, H. (1999, February 19). A-level maths equals money, Times Educational Supplement, p. 1 .

Mendick, H. (2003) Choosing maths/doing gender; a look at why there are more boys than girls in advanced mathematics classes in England, in: L. Burton (Ed.) Which way social justice for mathematics education? (Westport, CT and London, Praeger).

Mendick, H. (2005) A beautiful myth? The gendering of being/doing 'good at maths', Gender and Education (forthcoming, Vol. 17).

Plummer, K. (1995) Telling sexual stories (London, Routledge).

Povey, H. (1997) Beginning mathematics teachers' ways of knowing: the link with working for emancipatory change, Curriculum Studies, 5, 329-342.

Rose, N. (1999) Governing the soul (London, Free Association Books).

Sells, L. (1980) The mathematics filter and the education of women and minorities, in: L. H. Fox, L. Brody \& D. Tobin (Eds) Women and the mathematical mystique (Baltimore, MD, John Hopkins University Press).

Shaw, J. (1995) Education, gender and anxiety (London, Taylor \& Francis).

Skeggs, B. (1997) Formations of class and gender (London, Sage).

Skovsmose, O. (1994) Towards a philosophy of critical mathematics education (Dordrecht, Kluwer 
Academic Publishers).

The Guardian (2002a) GCSE results 2002. Available online at:

http://education.guardian.co.uk/gcses2002/table/0,12348,778454,00.htm (accessed 2 November 2004).

The Guardian (2002b) A-level results 2002. Available online at:

http://education.guardian.co.uk/alevels2001/tables/0,10951,774597,00.html (accessed 2 November 2004).

The Guardian (2003a) GCSE results 2003: maths-technology (including all subjects). Available online

at: http://education.guardian.co.uk/alevels2003/story/0,13394,1018079,00.html (accessed 2 November 2004).

The Guardian (2003b) A-level results 2003. Available online at: http://education.guardian.co.uk/gcses2003/story/0,13395,1026550,00.html (accessed 2 November 2004).

Thomas, K. (1990) Gender and subject in higher education (Buckingham, Open University Press).

Walkerdine, V. (1988) The mastery of reason: cognitive development and the production of rationality (London, Routledge).

Walkerdine, V. (1997) Redefining the subject in situated cognition theory, in: D. Kirshner \& J. A. Whitson (Eds) Situated cognition: social, semiotic and psychological perspectives (Mahwah, NJ, Lawrence Erlbaum).

Walkerdine, V. (1998) Counting girls out (London, Falmer).

Walkerdine, V., Lucey, H. \& Melody, J. (2001) Growing up girl: psychosocial explorations of gender and class (Basingstoke, Palgrave).

Whitehead, J. (1996) Sex stereotypes, gender identity and subject choices at A-level, Educational Research, 38, 147-160.

Willis, S. (1995) Gender reform through school mathematics, in: G. Kaiser \& P. Rogers (Eds) Equity in mathematics education: influences of feminism and culture (London, Falmer).

Witz, A. (1997) Women and work, in: D. Richardson \& V. Robinson (Eds) Introducing women's studies (London, Macmillan). 